\title{
IMPLEMENTASI KEBIJAKAN RETRIBUSI PELAYANAN PASAR DI PASAR SENTRAL KOTA GORONTALO
}

\author{
Ainun Fauziah Isnani Idrus ${ }^{1)}$, Rosman Ilato ${ }^{2)}$, Sri Yulianty Mozin ${ }^{3)}$ \\ Universitas Negeri Gorontalo ${ }^{1,2,3}$ \\ Alamat korespondensi: Afidrus21@gmail.com
}

\begin{abstract}
ABSTRAK
Penelitian ini bertujuan untuk mengetahui dan mendeskripsikan (1) implementasi kebijakan retribusi pelayanan pasar di Pasar Sentral Kota Gorontalo, dan (2) faktor pendukung dan penghambat dalam implementasi kebijakan retribusi pelayanan pasar di Pasar Sentral Gorontalo. Metode penelitian ini adalah deskriptif kualitatif.Teknik pengumpulan data melalui observasi, wawancara dan dokumnetasi.Teknik analisis data melalui reduksi data, penyajian data, dan penarikan kesimpulan.

Hasil penelitian (1) strategi implementasi kebijakan pengelolaan retribusi pelayanan pasardi Pasar Sentral Kota Gorontalo baik dalam tahap perencanaan, pelaksanaan, monitoring dan evaluasi sudah terlaksana namun belum optimal. Pada tahap perencanaan belum efektif untuk mencapai target realisasi penerimaan tahunan. Pada tahap pelaksanaan belum optimal dalam hal penerimaan retribusi yang belum memenuhi target capaian sebagaimana yang telah direncanakan dalam rencana tahunan. Pada tahap monitoring harian oleh petugas pemungut retribusi pelayanan pasar belum maksimal karena dilakukan seminggu sekali dari yang seharusnya setiap hari; (2) faktor pendukung implementasi kebijakan pengelolaan retribusi pelayanan pasar di Pasar Sentral Kota Gorontalo yaitu Pertama, komunikasi yang lancar dan baik antara semua pihak yang terlibat. Kedua, struktur birokrasi melalui SOP yang jelas yang memudahkan para pelaku untuk melaksanakan kebijakan dan sedikit fregmentasi dalam penyebaran tanggung jawab; (3) faktor penghambat implementasi kebijakan pengelolaan retribusi pelayanan pasar di Pasar Sentral Kota Gorontalo yaitu Pertama, sumber daya baik keterbatasan jumlah sumber daya manusia petugas pemungut retribusi dan belum dimanfaatkannya sistem informasi akuntansi dalam pemungutan dan penyetoran retribusi pelayanan pasar. Kedua, sikap petugas pemungut retribusi maupun pedagang yang kurang antusias.
\end{abstract}

Kata kunci: Implementasi; Kebijakan; Retribusi Pelayanan Pasar 


\begin{abstract}
This study aims to determine and describe (1) the implementation of market service retribution policy in the Pasar Sentral, Gorontalo City, and (2) the supporting and inhibiting factors in the implementation of market service retribution policy in the Pasar Sentral, Gorontalo City. This research used deskriptive qualitative method. Data collection was conducted through observation, interviews and documentation. Data analysis was conducted through data reduction, data presentation, and drawing conclusions.

The results of the study (1) the strategy of implementing market service retribution policy in the Pasar Sentral, Gorontalo City in the planning, implementation, monitoring and evaluation stages have been implemented but not yet optimal. At the planning stage has not been effective in achieving the annual revenue realization target. At the implementation stage, it is not optimal in terms of revenue collection that does not meet the achievement targets as planned in the annual plan. At the daily monitoring stage, the market service levies levies are not maximized because they are conducted once a week than they should every day; (2) supporting factors for implementing market service levies policy in the Gorontalo City, namely First, smooth and good communication between all parties involved. Second, a bureaucratic structure through a clear SOP that makes it easy for actors to implement policies and a bit of fragmentation in the distribution of responsibilities; (3) the inhibiting factors of the implementation of market service retribution policy in the Pasar Sentral, Gorontalo City are: First, good resources are limited in the number of human resources levies collection officers and the accounting information system has not been utilized in collecting and depositing market service fees.Second, the attitude of the levies collectors and traders who are less enthusiastic.
\end{abstract}

\title{
Keywords: Implementation; Policy; Market ServiceRetribution
}




\section{Pendahuluan}

Retribusi Pelayanan Pasar merupakan pungutan retribusi sebagai pembayaran atas penyediaan fasilitas pasar tradisional/ sederhana, berupa pelataran, los, kios, yang dikelola Pemerintah Daerah.Khususnya Pemerintah Daerah Kota Gorontalo, disediakan untuk pedagang.

Salah satu usaha yang dilakukan oleh Pemerintah Daerah Kota Gorontalo dalam mengelola retribusi pasar ini adalah memberikan pelayanan kepada masyarakat sesuai dengan apa yang telah mereka bayarkan kepada pemerintah. Pelayanan publik sebagai indikator utama bagi Pemerintah Daerah Kota Gorontalo dalam menyelenggarakan pemerintahan harus dilaksanakan sesuai dengan peraturan yang berlaku dan dikelola dengan baik, karena pengelolaan retribusi pasar tidak dapat dilepaskan dari pelayanan yang diberikan. Terkait dengan pengelolaan retribusi pasar oleh Pemerintah Daerah Kota Gorontalo yang menjadi implementor dalam pengelolaan retribusi pasar adalah Dinas Perindustrian dan Perdagangan Kota Gorontalo yang membangun kerjasama dengan Badan Pendapatan, Pengelolaan Keuangan dan Aset Daerah Kota Gorontalo (DPPKAD), Pengelola Pasar, dan masyarakat selaku pedagang di pasar tersebut.

Harapannya dengan diimplementasikannya Peraturan Daerah Nomor 17 Tahun 2011 tentang pelayanan retribusi pasar, maka pelayanan retribusi pasar dapat berjalan dengan optimal dan memuaskan masyarakat, karena pada dasarnya implementasi kebijakan dalam pelayanan pasar dalam pelaksanaan dan pengawasan dalam pengelolaan retribusi pasar tersebut dimaksudkan untuk menjaga agar kegiatan dalam suatu sistem pengelolaan retribusi pasar sesuai dengan rencana yang ditentukan. Selain itu, pengawasan ini ditujukan untuk mengetahui kelemahannya yang dihadapi dalam pemungutan, sehingga mempengaruhi tingkat penerimaan.

Berdasarkan hasil observasi menunjukkan pengelolaan retribusi pelayanan pada Pasar Sentral Kota Gorontalo belum optimal.Hal ini dapat dilihat dari perencanaan, pelaksanaan, monitoring dan evaluasi yang belum optimal dijalankan.Dalam hal perencanaan, kebijakan retribusi pelayanan pasar di Pasar Sentral Gorontalo dapat dikatakan belum optimal.Hal ini dapat dilihat dari adanya ketidaktercapaian antara besaran retribusi yang masuk dengan yang ditargetkan.

Berdasarkan data dalam dokumen pengelolaan Pasar Sentral Kota Gorontalo per bulan Desember 2019 terlihat target dan capaian jumlah retribusi yang masuk sebagaimana pada Tabel 1berikut.

\section{Tabel 1Target dan Capaian Retribusi Pasar Sentral Kota Gorontalo Tiga Tahun Terakhir}

\begin{tabular}{l|l|l}
\hline Tahun & \multicolumn{1}{|c|}{ Target } & \multicolumn{1}{c}{ Capaian } \\
\hline 2017 & $813.731 .622,-$ & $736.512 .323,-$ \\
\hline 2018 & $823.419 .915,-$ & $811.536 .826,-$ \\
\hline 2019 & $1.053 .370 .750,-$ & $815.205 .250,-$ \\
\hline \multicolumn{2}{|l|}{ Sumber: Dinas Perindustrian dan Perdagangan } \\
Kota Gorontalo Tahun 2020
\end{tabular}

Target dan capaian pada Tabel 1menunjukkan capaian dalam retribusi pelayanan pasar dalam tiga tahun terakhir cenderung lebih rendah dari yang ditargetkan.Hal ini bermakna perencanaan belum dilakukan dengan matang.Hal lain yang belum optimal dalam implementasi kebijakan retribusi pelayanan pasar di Pasar Sentral 
Gorontalo adalah pelaksanaan retribusi pelayanan pasar belum efektif. Kondisi ini ditunjukkan adanya ketidaktepatan waktu pihak pedagang wajib retribusi untuk menyetorkan retribusi kepada pihak kolektor retribusi, bahkan ada juga pihak pedagang wajib retribusi yang tidak mau membayar sanksi administrasi keterlambatan.Selain itu ada beberapa pedagang wajib retribusi yang membayar tidak sesuai besaran yang wajib dibayarkannya.

\section{Kajian Teori}

\subsection{Konsep Kebijakan Publik}

Kebijakan publik menurut Keban (2004:55) merupakan serangkaian prinsip atau kondisi yang diinginkan, sebagai suatu produk, kebijakan dipandang sebagai serangkaian kesimpulan atau rekomendasi. Sebagai suatu proses, kebijakan dipandang sebagai suatu cara dimana melalui cara tersebut suatu organisasi dapat mengetahui apa yang diharapkan darinya, yaitu program dan mekanisme dalam mencapai produknya, dan sebagai suatu kerangka kerja, kebijakan merupakan suatu proses tawar menawar dan negoisasi untuk merumus isu-isu dan metode implementasinya. Kebijakan publik menurut Dye (2008:1) adalah apapun pilihan pemerintah untuk melakukan atau tidak melakukan (public policy is whatever goverments choose to do or not to do).

Arifin (2014:52) mengungkap pendapat Tachjan (2006:63) dalam bahwa: "Implementasi kebijakan publik, disamping dapat dipahami sebagai salah satu aktivitas dari adminitrasi publik sebagai institusi (birokrasi) dalam proses kebijakan publik, dapat dipahami sebagai salah satu lapangan studi administrasi publik sebab pandangan tersebut, mengarahkan kita bahwa produk kebijakan apapun yang akan diimplementasikan haruslah mengedepankan pemahaman terhadap kebijakan publik tersebut,baik dari prospektif politik maupun dari prospektif administratif secara berimbang.

Keberhasilan implementasi kebijakan akan ditentukan oleh banyaknya variabel atau faktorfaktor yang masing-masing variabel tersebut saling berhubungan satu sama lain. Dalam pandangan Edwards IIIyang dikutip Subarsono (2015:90), implementasi kebijakan dipengaruhi oleh empat variabel, yaitu: (1) komunikasi, (2) sumber daya, (3) sikap pelaksana, dan (4) struktur birokrasi.

\section{Konsep Retribusi Pasar}

Retribusi pasar menurut Peraturan Daerah No.17 Tahun 2011, adalah pembayaran atas pelayanan penyediaan fasilitas pasar berupa pelataran dan los yang dikelola pemerintah daerah dan khusus disediakan untuk pedagang.Sementara itu Bambang (2005) memberikan pengertian retribusi pasar adalah retribusi atas fasilitas pasar tradisional/sederhana yang berupa pelataran atau los yang kelola pemerintah daerah dan khusus disediakan untuk pedagang, tidak termasuk yang dikelola perusahan daerah pasar.

Retribusi pasar atau retribusi pelayanan pasar merupakan salah satu jenis retribusi jasa umum yang keberadaannyaa sangat dimanfaatkan oleh masyarakat.Ada pun yang menjadi subyek dari retribusi pasar adalah orang pribadi atau badan yang menggunakan fasilitas pasar, Sedangkan obyek retribusi meliputi: (1) penyediaan fasilitas pasar/tempat (kios, los, front took, dan pelataran) pada pasar yang disediakan oleh pemerintah daerah, (2) setiap kegiatan membongkar muatan hasil bumi, laut, ternak, dan barang dagangan lainnya pada radius 200 meter dari paar, (3) keramaian pasar, (4) Biaya balik nama pemakai. 


\section{Metode}

Pendekatan yang digunakan oleh peneliti adalah dengan menggunakan pendekatan kualitatif dimaksudkan untuk memahami fenomena dalam implementasi kebijakan retribusi pelayanan pasar di Pasar Sentral Kota Gorontalo secara holistik dengan cara menggambarkan dalam bentuk kata-kata dan bahasa secara ilmiah dengan memanfaatkann berbagai metode ilmiah. Penelitian ini dilaksanakan di Dinas Perindustrian dan Perdagangan Kota Gorontalo dan Pasar Sentral Kota Gorontalo. Dasar penetapan lokasi tersebut mempertimbangkan Pasar Sentral Kota Gorontalo lokasinya berada di pusat kota yang mudah diakses dan menjadi pasar induk di Kota Gorontalo. Selain itu, dibandingkan dengan pasar lainnya di Kota Gorontalo, Pasar Sentral merupakan pasar terlengkap yang menyediakan berbagai kebutuhan masyarakat.

Target/ sumber penelitian yaitu Kepala Bidang Perdagangan Dinas Perindustrian dan Perdagangan Kota Gorontalo, Kepala Seksi Usaha Perdagangan Umum, Seksi Sarana Distribusi Perdagangan, Petugas Pemungut Retribusi dan pedagang di Pasar Sentral Kota Gorontalo yang dapat ditemui saat pengumpulan data.

Tipe penelitian ini adalah deskriptif untuk memberikan data yang seteliti mungkin tentang implementasi kebijakan retribusi pelayanan pasar di Pasar Sentral Kota Gorontalo. dengan demikian prosedur penelitian ini berpusat pada pada masalahmasalah atau fenomena yang ada pada saat penelitian dilakukan atau masalah yang bersifat aktual, kemudian menggambarkan fakta-fakta tentang masalah yang diselidiki sebagaimana adanya diiringi dengan interpretasi yang rasional dan akurat. Selanjutkan peneliti memberi gambaran yang sejelas-jelasnya tentang implementasi kebijakan retribusi pelayanan pasar di Pasar Sentral Kota Gorontalo.

Teknik pengumpulan data penelitian ini dilakukan melalui (1) observasi langsung di lapangan untuk mengetahui dan menganalisis berbagai masalah dan keadaan yang sebenarnya; (2) wawancara untuk memperoleh berbagai keterangan secara lisan melalui percakapan dan berhadapan muka dengan informan penelitian; dokumentasi untuk mengumpulkan data beberapa catatan dan laporan-laporan yang berhubungan dengan data yang digali, sepeprti gambaran umum lokasi penelitian, struktur organisasinya, serta kualitas dan pelayannya.

Analisis data dilakukan dengan langkah (1) mengumpulkan data di lokasi penelitian melalui observasi, wawancara, dan dokumentasi dengan menentukan strategi pengumpulan data yang dipandang tepat dan untuk menentukan fokus serta pendalaman data pada proses pengumpulan data berikutnya; (2) melakukan reduksi data yaitu sebagai proses seleksi, pemfokusan, pengabstrakan, transformasi data kasar yang ada di lapangan langsung, dan diteruskan pada waktu pengumpulan data, dengan demikian reduksi data dimulai sejak peneliti memfokuskan wilayah penelitian; (3) menyajikan data yaitu rangkaian organisasi informasi yang memungkinkan penelitian dilakukan. Penyajian data diperoleh berbagai jenis, jaringan kerja, keterkaitan kegiatan atau tabel; (4) menarik kesimpulan yaitu dalam pengumpulan data, peneliti harus mengerti dan tanggap terhadap sesuatu yang diteliti langsung di lapangan dengan menyusun pola-pola pengarahan sebab akibat.

\section{Hasil Penelitian dan Pembahasan}




\subsection{Strategi Implementasi Kebijakan}

\section{Pengelolaan Retribusi Pelayanan Pasar}

\section{Perencanaan}

Perencanaan dalam implementasi kebijakan pengelolaan retribusi pelayanan pasar di Pasar Sentral Kota Gorontalo dilaksanakan sebelum kebijakan retribusi pelayanan pasar dimplementasikan.Hasil penelitian menunjukan perencanaanretribusi pelayanan pasar di pasar Sentral Gorontalo sudah terlaksana dengan menggunakan kombinasi pendekatan top downbottom up. Top down yaitu pemerintah daerah membentuk Peraturan Daerah Nomor 17 tahun 2011 tentang Retribusi Pelayanaan Pasar di Kota Gorontalo dengan memperhatikan ketentuan perundang-undangan dan peraturan di atasnya yang selanjutnya dijabarkan ke dalam Rencana Tahunan Bidang Perdagangan Dinas Perindustrian dan Perdagangan Kota Gorontalo untuk dilaksanakan secara terpadu di pasar Sentral kota Gorontalo. Bottom up disusun berdasarkan pertimbangan kemampuan masyarakat dan aspek keadilan.Namun demikian, tahap perencanaan belum efektif untuk mencapai target realisasi penerimaan tahunan retribusi pelayanan pasar di Pasar sentral Kota Gorontalo.

Beberapa hal yang dirumuskan dalam Peraturan Daerah Nomor 17 Tahun 2011 khususnya mengenai besaran tarif sudah diperhitungkan oleh pengambil kebijakan yaitu Pemerintah Daerah terdiri dari DPRD Gorontalo dan Walikota Gorontalo dengan mempertimbangkan kemampuan masyarakat dan aspek keadilan. Dengan demikian secara tidak langsung masyarakat terlibat dalam kegiatan perencanaan ini. Dapat dilihat perencanaan yang dilakukan berjalan dua arah, yaitu secara top down dimana para pengambil kebijakan yang merencanakan dan menentukan besaran tarif retribusi pelayanan pasar berdasarkan ketentuan dalam perundang-undangan dan peraturan di atasnya. Secara bottom up dengan memperhitungkan dan melihat kemampuan daya bayar masyarakat wajib retribusi.

Temuan penelitian tersebut jika dikaitkan dengan teori Bryson (2016:35-54) dan hasil penelitian Andika, dkk (2019), maka instansi pemerintah dalam hal ini Dinas Perindustrian dan Perdagangan Kota Gorontalo perlu menerapkan sebuah proses manajemen strategis yang bersifat dinamis agar tujuan dari strategi tersebut sesuai dengan perencanaan strategis yang telah dilakukan. Tidak menutup kemungkinan perencanaan strategis tersebut dilakukan secara terus menerus sesuai dengan perubahan situasi eksternal-internal yang dihadapi organisasi.Jika dikaitkan dengan teori Kadji (2008:59), maka pendekatan bersifat top down dan bottom up yang sudah dilakukan dalam perencanaan implementasi kebijakan retribusi pelayanan pasar di Pasar Sentral Kota Gorontalo dapat mendorong perubahan Dinas Perindustrian dan Perdagangan Kota Gorontalo untuk meningkatkan efisiensi ataupun mencapai outcome yang lebih baik, karena dengan proses perencanaan yang matang akan berdampak pada berjalannya program kerja dengan baik.

\section{Pelaksanaan}

Pelaksanaan dalam implementasi kebijakan pengelolaan retribusi pelayanan pasar di Pasar Sentral Kota Gorontalo dilaksanakan berdasarkan Peraturan Daerah Nomor 17 Tahun 2011 tentang Retribusi Pelayanan Pasar di Kota Gorontalo dilihat dari tahap pelaksanaan menunjukkan retribusi pelayanan pasar di Pasar Sentral Kota Gorontalo dalam hal pembayaran atas penyediaan fasilitas 
pasar yang berupa halaman/ pelataran, los dan atau kios yang dikelola Pemerintah Daerah dan khusus disediakan untuk pedagang sudah dilaksanakan sesuai dengan ketentuan-ketentuan yang ada dalam Peraturan Daerah Nomor 17 Tahun 2011. Namun dalam pelaksanaan pemungutan retribusi pelayanan pasar belum optimal dalam hal penerimaan retribusi belum memenuhi target capaian sebagaimana yang telah direncanakan dalam rencana tahunan.

Temuan penelitian tersebut, jika dikaitkan denganElwan (2019:38), maka dengan diimplementasikannya Peraturan Daerah Nomor 17 Tahun 2011 tentang Retribusi Pelayanan Pasar telah mampu menggerakkan para pejabat di Dinas Perindustrian dan Perdagangan Kota Gorontalo dimulai dari pimpinan atas yaitu Kepala Dinas sampai pelaksana di lapangan untuk melakukan aktifivas-aktifitvas dalam retribusi pelayanan pasar. Hal ini berarti esensi utama dari implementasi kebijakan retribusi pelayanan pasar adalah pemahaman para implementor terhadap apa yang seharusnya dilakukan sesudah Peraturan Daerah Nomor 17 Tahun 2011dinyatakan berlaku.

\section{Monitoring dan evaluasi}

Monitoring dan evaluasi dalam implementasi kebijakan retribusi pelayanan pasar di Pasar Sentral Kota Gorontalo dimaksudkan untuk mencocokkan apakah kegiatan operasional di lapangan sesuai dengan rencana yang telah ditetapkan dalam mencapai tujuan dari kebijakan retribusi pelayanan pasar tersebut.Temuan penelitian dilihat dari tahap monitoring dan evaluasi menunjukkan tindakan memeriksa penyimpangan-penyimpangan, kesalahan atau kekeliruan bahkan kebijakankebijakan yang tidak tepat dalam retribusi pelayanan pasar di Pasar Sentral Gorontalo, serta penilaian terhadap langkah-langkah menuju perbaikan terus menerus terhadap implementasi kebijakan pengelolaan retribusi pelayanan pasar di Pasar Sentral Gorontalo oleh pihak terkait yaitu Kepala Dinas, Kepala Bidang dan Kepala Seksi sudah dilaksanakan sesuai dengan ketentuanketentuan yang ada dalam Peraturan Daerah Nomor 17 Tahun 2011 dan Rencana Program Kegiatan Tahunan Dinas Perindustrian dan Perdagangan Kota Gorontalo Tahun 2019. Namun dalam monitoring harian oleh petugas pemungut retribusi pelayanan pasar belum maksimal dimana dilakukan seminggu sekali dari yang seharusnya setiap hari.

Jika dikaitkan dengan hasil penelitian Siregar (2018:100), maka esensi utama monitoring dan evaluasi oleh Dinas Perindustrian dan Perdagangan Kota Gorontalo telah diarahkan untuk mengetahui apakah pelaksanaan, dalam hal ini para implementor mampu merealisasikan target yang telah direncanakan semula dan bagaimana monitoring dan evaluasi itu sendiri mampu menjalankan fungsinya dalam rangka meningkatkan Pendapatan Asli Daerah Kota Gorontalo yang selanjutnya digunakan untuk membiayai pelaksanaan pembangunan di daerah khususnya meningkatkan pelayanan di Pasar Sentral Kota Gorontalo.

\subsection{Faktor Pendukung dan Penghambat Implementasi kebijakan}

a. Komunikasi

Komunikasi adalah model pertukaran informasi yang terjadi dalam implementasi kebijakan retribusi pelayanan pasar di Pasar Sentral Kota Gorontalo dilakukan dengan pendekatan secara persuasif dan personal. Para petugas pemungut retribusi datang langsung menyampaikan 
pemberitahuan-pemberitahuan kepada para pedagang. Hal ini ssebagaimana teori Edwards III yang dikutip Subarsono (2015:90), maka implementasi yang efektif ini terwujud disebabkan adanya pengetahuan dari para pembuat keputusan dalam hal ini Pemerintah Daerah yaitu DPRD dan Walikota Gorontalo dan para implementor di Dinas Perindustrian dan Perdagangan Kota Gorontalo sampai pada para pedagang di pasar terhadap apa yang akan dikerjakan dalam retribusi pelayanan pasar.

\section{b. Sumber daya}

Sumber daya terdiri dari petugas retribusi dan sarana yang digunakan dalam implementasi retribusi pelayanan pasar di Pasar Sentral Kota Gorontalo. Sehubungan dengan sumber daya petugas pelaksana, hasil penelitian menunjukan bahwa sumber daya manusia dalam retribusi pelayanan pasar belum mendukung. Jumlah petugas pemungut dan jumlah pedagang itu belum memenuhi perbandingan jumlah yang rasional. Jumlah pedagang 1.019 pedagang yang tersebar di Pasar Sentral Kota Gorontalo. Sementara jumlah petugas pemungut hanya 24 orang. Ini tidak ideal. Hal ini menjadi penghambat di lapangan tidak tercapainya target kinerja harian. Selain dilihat dari sumber daya manusia, sumber daya dilihat dari sarana yang digunakan dalam implementasi kebijakan retribusi pelayanan pasar di Pasar Sentral Kota Gorontalo belum menggunakan sistem informasi akuntansi, sehingga menghambat dalam upaya pelaksanaan pelaporan keuangan yang cepat dan akurat.

\section{Struktur birokrasi}

Struktur birokrasi adalah kejelasan Standard Operating Procedure (SOP) dan penyebaran tanggung jawab diantara pihak-pihak yang terkait dengan implementasi kebijakan retribusi pelayanan pasar di Pasar Sentral Kota Gorontalo. Selain $S O P$,penyebaran wewenang dan tanggungjawab dalam implementasi kebijakan retribusi pelayanan pasar di Pasar Sentral Kota Gorontalo dilakukan melalui koordinasi dengan mendasarkan pada tugas pokok dan fungsi masing-masing. Dalam struktur birokrasi implementasi kebijakan retribusi pelayanan pasar di Pasar Sentral Kota Gorontalo menunjukkan adanya sedikit fragmentasi dimana pihak yang terlibat langsung adalah Dinas Perindustrian dan Perdagangan Kota Gorontalo.

Dengan adanya SOP yang jelas telah mendukung kelancaran implementasi kebijakan retribusi pelayanan pasar di Pasar Sentral Kota Gorontalo dimana semua implementor yang terlibat dalam kebijakan ini menjadi mudah dalam melaksanakan kebijakan. Sedangkan adanya sedikit fragmentasi telah mendukung komunikasi dan meningkatkan kemampuan para pejabat yang ada untuk melakukan koordinasi.

Melihat temuan penelitian tersebut, struktur birokrasi merupakan faktor pendukung dalam implementasi kebijakan retribusi pelayanan pasar di Pasar Sentral Kota Gorontalo baik dari SOP struktur birokrasi melalui SOP yang jelas yang memudahkan para pelaku untuk melaksanakan kebijakan dan sedikit fregmentasi dalam penyebaran tanggung jawab.Jika dikaitkan dengan teori Edwards III yang dikutip Subarsono (2015:90), maka struktur birokrasi memberikan pengaruh positif dan signifikan terhadap implementasi kebijakan retribusi pelayanan pasardi Pasar Sentral Kota Gorontalo, hal ini antara lain telah didukung oleh kejelasan SOP yang menjadi pedoman bagi setiap implementor dalam bertindak. 


\subsection{Simpulan}

1. Strategi implementasi kebijakan pengelolaan retribusi pelayanan pasardi Pasar Sentral Kota Gorontalo baik dalam tahap perencanaan, pelaksanaan, monitoring dan evaluasi sudah terlaksana namun belum optimal. Pada tahap perencanaan belum efektif untuk mencapai target realisasi penerimaan tahunan. Pada tahap pelaksanaan belum optimal dalam hal penerimaan retribusi yang belum memenuhi target capaian sebagaimana yang telah direncanakan dalam rencana tahunan. Pada tahap monitoring harian oleh petugas pemungut retribusi pelayanan pasar belum maksimal karena dilakukan seminggu sekali dari yang seharusnya setiap hari.

2. Faktor pendukung implementasi kebijakan pengelolaan retribusi pelayanan pasardi Pasar Sentral Kota Gorontalo yaitu Pertama, komunikasi yang lancar dan baik antara semua pihak yang terlibat.Kedua, struktur birokrasi melalui SOP yang jelas yang memudahkan para pelaku untuk melaksanakan kebijakan dan sedikit fregmentasi dalam penyebaran tanggung jawab.

3. Faktor penghambat implementasi kebijakan pengelolaan retribusi pelayanan pasardi Pasar Sentral Kota Gorontalo yaitu Pertama, sumber daya baik keterbatasan jumlah sumber daya manusia petugas pemungut retribusi dan belum dimanfaatkannya sistem informasi akuntansi dalam pemungutan dan penyetoran retribusi pelayanan pasar.Kedua, sikap petugas pemungut retribusi maupun pedagang yang kurang antusias.
1. Pihak yang terlibat dalam perencanaan supaya memperhitungkan secara cermat aspek target pendapatan retribusi baik menyangkut jumlah los dan besarannya juga jumlah pedagang, sehingga secara real angka yang diperoleh menjadi akurat.

2. Para kolektor perlu membuat target capaian harian dan harus konsisten dalam mengejar target pencapaian penerimaan harian tersebut.

3. Monitoring oleh kolektor perlu digiatkan secara intens setiap hari terutama dalam hal kontrol pedagang yang belum melakukan pembayaran dan masih ada tunggakan.

4. Para pihak terkait baik dinas, kolektor dan pedagang perlu mengefektifkan komunikasi melalui pembuatan grup WhatsApp untuk penyebaran dan pertukaran informasi secara rutin.

5. Pihak Dinas Perindustrian dan Perdagangan Kota Gorontalo harus menambah jumlah kolektor di lapangan.

6. Pemerintah Daerah Kota Gorontalo perlu menyediakan sebuah sistem aplikasi pengolahan data penerimaan retribusi pasar yang sangat tepat untuk mempermudah penginputan data secara lebih efektif dan mencegah adanya redudansi data. Pegawai dan pihak terkait akan lebih mudah dalam mengeloah data penerimaan retribusi pasar.

\section{DAFTAR PUSTAKA}

Andika, A.B.R.S., Yudartha, I.P.D., Purnamaningsih, P.E. (2018). Strategi Peningkatan Pendapatan Asli Daerah (PAD) Melalui Retribusi Objek Wisata (Studi Kasus di Dinas Pariwisata dan Kebudayaan Kabupaten Bangli). Ojs.unud.ac.id

\subsection{Saran}


Arifin, Z. (2014). Penelitian Pendidikan: Metode dan Paradigma Baru.Bandung: PT Remaja Rosdakarya.

Bryson, J. (2016). Perencanaan Strategis Bagi Organisasi Sosial.Yogyakarta: Pustaka Pelajar.

Elwan, L.O.M. (2019). Manajemen Pengelolaan Retribusi Pasar Dalam Meningkatkan Pendapatan Asli Daerah Di Kota Kendari. Jurnal Publicuho 12(3), 32-41.

Gronlund, N.E. \& Linn, R.L. (1990). Measurement and evaluation in teaching. ( $\left.6^{\text {th }} e d.\right)$. New York: Macmillan.

https://60dtk.com/pasar-sentral-gorontalo-danrenovasi-yang-di-janjikan-pemerintah/Di akses tgl 29 Januari 2020, pada pukul 13:15 WITA

https://gopos.id/pasar-sentral-kota-gorontalosegera-direnovasi/ Di akses tgl 29 Januari 2020, pada pukul 22:10 WITA

https://www.antaranews.com/berita/803830/preside n-jokowi-tiba-di-gorontalo Di akses tgl 29 Januari 2020, pada pukul 13:30 WITA

Keban, Y.T. (2004). Enam Dimensi Strategis Administrasi Publik, Konsep, Teori dan Isu. Yogyakarta: Gava Media

Peraturan Daerah Kota Gorontalo No 17 tahun 2011 Tentang Retribusi Pelayanan Pasar Kota Gorontalo

Peraturan Pemerintah Nomor 66 Tahun 2001 tentang Retribusi Daerah.

Siregar, K. (2018). Optimalisasi Retribusi Pasar Dalam Meningkatkan Pendapatan Asli Daerah Kabupaten Dompu Provinsi Nusa Tenggara Barat. Jurnal Dharma Praja11(2), 93-106.

Subarsono.(2015). Analisis Kebijakan Publik, Konsep Teori dan Aplikasi.Yogyakarta: Pustaka Pelajar.

Syafiie, I.K. (2006). Ilmu Administrasi Publik. Jakarta: PT Rineka Cipta.

Undang-undang Nomor 34 Tahun 2000 Tentang Pajak Daerah dan Retribusi Daerah
Widodo, J. (2010). AnalisisKebijakan Publik. Malang: Bayumedia Publishing. 